Research Paper

\title{
Morphology and mycelial growth rate of Pleurotus spp. strains from the Mexican mixtec region
}

\author{
P.C. Guadarrama-Mendoza ${ }^{1}$, G. Valencia del Toro ${ }^{2}$, R. Ramírez-Carrillo ${ }^{3}$, \\ F. Robles-Martínez ${ }^{2}$, J. Yáñez-Fernández ${ }^{2}$, M.E. Garín-Aguilar ${ }^{4}$, C.G. Hernández ${ }^{1}$, \\ G. Bravo-Villa ${ }^{1}$ \\ ${ }^{1}$ Instituto de Agroindustrias, Universidad Tecnológica de la Mixteca, Huajuapan de León, \\ Oaxaca, México. \\ ${ }^{2}$ Unidad Profesional Interdisciplinaria de Biotecnología, Instituto Politécnico Nacional, Col. Ticoman, \\ México D.F., México. \\ ${ }^{3}$ Facultad de Química, Universidad Nacional Autónoma de México, México D.F., México. \\ ${ }^{4}$ Facultad de Estudios Superiores Iztacala, Universidad Nacional Autónoma de México, Tlalnepantla, \\ Estado de México, México.
}

Submitted: September 13, 2012; Approved: March 14, 2014.

\begin{abstract}
Two native Pleurotus spp. strains (white LB-050 and pale pink LB-051) were isolated from rotten tree trunks of cazahuate (Ipomoea murucoides) from the Mexican Mixtec Region. Both strains were chemically dedikaryotized to obtain their symmetrical monokaryotic components (neohaplonts). This was achieved employing homogenization time periods from 60 to $65 \mathrm{~s}$, and 3 day incubation at $28^{\circ} \mathrm{C}$ in a peptone-glucose solution (PGS). Pairing of compatible neohaplonts resulted in 56 hybrid strains which were classified into the four following hybrid types: $\left(\mathrm{R}_{1-\mathrm{n}} \mathrm{xB}_{1-\mathrm{n}}, \mathrm{R}_{1-\mathrm{n}} \mathrm{xB}_{2-1}, \mathrm{R}_{2-\mathrm{n}} \mathrm{xB}_{1-\mathrm{n}}\right.$ and $\mathrm{R}_{2-\mathrm{n}} \mathrm{xB}_{2-1}$ ). The mycelial growth of Pleurotus spp. monokaryotic and dikaryotic strains showed differences in texture (cottony or floccose), growth (scarce, regular or abundant), density (high, regular or low), and pigmentation (off-white, white or pale pink). To determine the rate and the amount of mycelium growth in malt extract agar at $28^{\circ} \mathrm{C}$, the diameter of the colony was measured every $24 \mathrm{~h}$ until the Petri dish was completely colonized. A linear model had the best fit to the mycelial growth kinetics. A direct relationship between mycelial morphology and growth rate was observed. Cottony mycelium presented significantly higher growth rates $(p<0.01)$ in comparison with floccose mycelium. Thus, mycelial morphology can be used as criterion to select which pairs must be used for optimizing compatible-mating studies. Hybrids resulting from cottony neohaplonts maintained the characteristically high growth rates of their parental strains with the hybrid $\mathrm{R}_{1-\mathrm{n}} \mathrm{xB}_{1-\mathrm{n}}$ being faster than the latter.
\end{abstract}

Key words: Pleurotus, mycelial growth, mycelial morphology, hybrid strains, monokaryotization.

\section{Introduction}

Production of edible fungi is a biotechnological industry which is undergoing a continuous worldwide expansion. The four more important species based on their production and demand, are: 1) Agaricus bisporus (mushroom), in Europe, North America and Mexico; 2) Lentinula edodes (Shiitake) in Japan; 3) Pleurotus spp. (seta) in
México and South America, and 4) Volvariella volvacea in Asian countries (Martínez-Carrera and López-Martínez 2010).

The Pleurotus genus (Pleurotaceae, higher Basidiomycetes) includes a diverse group of aromatic edible fungi which have been praised for their culinary and high nutritional value due to the fact that they are rich in protein, fi-

Send correspondence to G. Valencia del Toro . Unidad Profesional Interdisciplinaria de Biotecnología, Instituto Politécnico Nacional, Av. Acueducto S/N, Barrio La Laguna, Col. Ticoman, 07340 México D.F., México. E-mail: gvovaltor@yahoo.com.mx. 
ber, vitamins and minerals (Chang and Miles 2004, Reis et al., 2012). Several Pleurotus species constitutes a very valuable protein source, especially in the rural areas of developing countries (Aguilar et al., 2002, Mata and Salmones 2003, Mayet et al., 2004). In addition to their nutritional value, these fungi produce important biomolecules (Papaspyridi et al., 2011), that include lectins, proteins, enzymes, organic acids, polysaccharides and glycoproteins with a number of biologic activities such as antitumoral (Lindequist et al., 2005), antimutagenic (Jose et al., 2002), antiinflamatory (Lull et al., 2005), antiviral (Ng and Wang 2004), antioxidant (Gregori et al., 2007) and which are capable to reduce the level of cholesterol in blood (Nuhu et al., 2011). Also, some Pleurotus species have been reported to be able to degrade and decolorize various dyes and aromatic organic compounds that are important environmental pollutants in the dyestuff industries (Novotny et al., 1999, Novotny et al., 2001, Vyas and Molitoris 1995). This property has generally been attributed to lignindegrading enzymes such as manganese-dependent peroxidase and laccase (Vyas and Molitoris 1995).

In 2009 the annual Pleurotus production in Mexico was estimated as 2920 tons, which represented the $6.3 \%$ of that years total edible fungi production (Martínez-Carrera and López-Martínez 2010). Despite the growing interest in Pleurotus production, most of the small-scale producing companies do not last for a long time due to a number of factors which include: product contamination, difficulty to obtain good quality spawns and poor adaptability of commercial strains to the local climatic conditions (De LeónMonzón 2004). Therefore, the cultivation of Pleurotus in tropical and subtropical climates requires the search of new strains capable to grow and produce fruit under diverse region-specific climatic conditions (Kashangura et al., 2006). In this regard, the development of a genetic improvement program should take advantage of the natural Pleurotus germplasm. Such program needs to consider: a) accurate species identification, b) characterization of the sexual compatibility between Pleurotus species lines, and c) collection and study of strains from different geographical locations to ensure diversity (Martínez-Carrera 2002, Petersen 1995a, Petersen 1995b, Vigalys et al., 1996, Vigalys et al., 1994, Vigalys et al., 1993).

The main aim of this research is to collect and characterize the germplasm of two native wild strains from the Mexican Mixtec region. With this study, the authors also intend to promote the production of Pleurotus spp. fungi in Mexico. A chemical dedikaryotization process was used for the recovery of symmetrical monokaryotic components, where the compatible neohaplonts produced different types of hybrid strains. Morphology and mycelium growth rate characteristics were compared between native, neohaplonts and hybrid strains.

\section{Materials and Methods}

\section{Voucher material}

The carpophores of the Pleurotus ssp., native strains denoted as LB-051 and LB-050 were isolated from rotten tree trunks of cazahuate (Ipomoea murucoides) located in the Universidad Tecnológica de la Mixteca in the city of Huajuapan de León, Oaxaca (174940 N, 97²4823 W, 1785 $\mathrm{m}$ asl.), during August and September 2010. The strains of Pleurotus spp. are stored in the culture collection of the Bioconversion Laboratory of the Department of Bioprocess, Unidad Profesional Interdisciplinaria de Biotechnología (UPIBI-IPN), México. Under the accession numbers: LB-050 and LB-051. The strains were collected by Paula Cecilia Guadarrama-Mendoza and Carlos Guillermo Hernández. The germplasm was obtained from vegetative cultures by performing consecutive mycelium inoculations on malt extract agar until an axenic culture was attained.

\section{Culture media}

The malt extract agar medium (MEA) was prepared by dissolving $9 \mathrm{~g}$ of malt extract and $12 \mathrm{~g}$ of Bacteriological Agar (Bioxon) in $600 \mathrm{~mL}$ of distilled water. The medium was autoclaved at $1.1 \mathrm{~kg}_{f} / \mathrm{cm}^{2}\left(121{ }^{\circ} \mathrm{C}\right)$ for $20 \mathrm{~min}$. Subsequently, $10 \mathrm{~mL}$ of the sterile medium were poured into Petri dishes $(90 \times 15 \mathrm{~mm})$, solidified and incubated at $28^{\circ} \mathrm{C}$ for $24 \mathrm{~h}$ for sterility testing. Petri dishes without contamination were used for isolation, propagation and storage of mycelium.

\section{Dedikaryotization solution (Peptone-Glucose Solution PGS)}

A dedikaryotization solution was prepared by dissolving $20 \mathrm{~g}$ of anhydrous glucose and $20 \mathrm{~g}$ of peptone $\mathrm{P}$ (Oxoid LP0037) in $1 \mathrm{~L}$ of distilled water. Aliquots of $50 \mathrm{~mL}$ were poured into glass jars and autoclaved at $1 \mathrm{~kg}_{\mathrm{f}} / \mathrm{cm}^{2}$ $\left(121^{\circ} \mathrm{C}\right)$ for $20 \mathrm{~min}$. After cooling, the jars were incubated at $28{ }^{\circ} \mathrm{C}$ for $24 \mathrm{~h}$ for sterility testing. Sterile media were used for the chemical dedikaryotization tests.

\section{Recovery and identification of monokaryotic components (neohaplonts)}

The chemical dedikaryotization method proposed by Leal-Lara and Eger-Hummel (1982) was used for obtaining the neohaplonts. A PGS solution was employed as the dedikaryotization medium and the following parameters were varied: homogenization time $(\mathrm{Ht})$, volume of inoculum (Vi) and incubation time (It).

The procedure consists of the following stages: 1) A small section of $0.8 \mathrm{~cm}$ of diameter was cut from the edge of a growing colony in MEA and re-cultured in petri dishes $(90 \times 15 \mathrm{~mm})$ with $10 \mathrm{~mL}$ of MEA. After 10 days of incubation at $28{ }^{\circ} \mathrm{C}$, the colonies covered the plates surface completely until they reached a diameter of $8.5 \mathrm{~cm}$. Afterwards, 
the dishs mycelial growth was divided in fourths and three of them were homogenized in a Waring Blender (8010S) homogenizer using an sterile jar and $50 \mathrm{~mL}$ of sterile water. Different homogenization times were used (Ht: 55, 60 and $65 \mathrm{~s})$ at $22,000 \mathrm{rpm}$. 2) Aliquots of the homogenized inoculum (Vi: 50 and $100 \mu \mathrm{L}$ ) were pipetted into jars that contained $50 \mathrm{~mL}$ of PGS, and incubated at $28^{\circ} \mathrm{C}$ until the new colonies formed small conglomerates. 3) The liquid culture was further homogenized with $50 \mathrm{~mL}$ of sterile distilled water for $60 \mathrm{s.}$ ) Aliquots of the homogenized culture (30, 60 and $90 \mu \mathrm{L})$ were spread on the MEA Petri dishes and incubated at $28^{\circ} \mathrm{C}$ until colonies were formed (It: 3 to 7 days). Following this, the plates were observed under the microscope. The colonies that developed hyphae without clamp connections (neohaplonts) were isolated and propagated individually on Petri dishes with MEA medium.

To identify the two types of monokaryotic components, the neohaplonts from the same strain were paired with each other in all possible combinations. Fragments of each monokaryon $(0.5 \mathrm{~cm})$ were placed on Petri dishes with $10 \mathrm{~mL}$ of MEA and incubated at $28^{\circ} \mathrm{C}$. Following this, the plates were regularly inspected under the microscope to determine the presence or absence of clamp connections. The presence of clamp connections between the two mated monokaryotic colonies indicated that their nucleous were of different type, whereas clamp connections absence indicated that the colonies had the same type of nucleus. According to this, neohaplonts were classified as $\mathrm{R}_{1-\mathrm{n}}$ and $\mathrm{R}_{2-\mathrm{n}}$ for the strain LB-051 and $\mathrm{B}_{1-n}$ and $\mathrm{B}_{2-\mathrm{n}}$ for the strain LB050. $R_{1-n}$ refers to all neohaplonts from the pale pink strain (LB-051) that belong to the nh1 type: $\mathrm{R}_{1-1}, \mathrm{R}_{1-2}, \mathrm{R}_{1-3}, \mathrm{R}_{1-4}$ and $R_{1-5}$. The $R_{2-n}$ term refers to all neohaplonts from the pinkish strain (LB-051) that belong to the nh2 type: $R_{2-1}$, $\mathrm{R}_{2-2} \mathrm{y} \mathrm{R}_{2-3}$. On the other hand, the $\mathrm{B}_{1-\mathrm{n}}$ term refers to all neohaplonts from the white strain (LB-050) that belong to the nh1 type: $\mathrm{B}_{1-1}, \mathrm{~B}_{1-2}, \mathrm{~B}_{1-3}, \mathrm{~B}_{1-4}, \mathrm{~B}_{1-5} \mathrm{y} \mathrm{B}_{1-6}$. The $\mathrm{B}_{2-\mathrm{n}}$ refers to the neohaplont $\mathrm{B}_{2-1}$ from the white strain (LB-050).

The reconstituted strains were obtained by performing an intra-specimen pairing (nh1 and nh2) of each parental strain: $\mathrm{R}_{1-\mathrm{n}} \mathrm{xR}_{2-\mathrm{n}}(\mathrm{LB}-051-\mathrm{r})$ and $\mathrm{B}_{1-\mathrm{n}} \mathrm{xB}_{2-\mathrm{n}}$ (LB-050-r).

\section{Production of hybrids strains of Pleurotus spp. by pairing compatible neohaplonts}

The two neohaplonts (nh1 and nh2) obtained from each native strain were paired in all possible combinations: $\left(\mathrm{R}_{1-\mathrm{n}} \mathrm{xB}_{1-\mathrm{n}}, \mathrm{R}_{1-\mathrm{n}} \mathrm{xB}_{2-1}, \mathrm{R}_{2-\mathrm{n}} \mathrm{xB}_{1-\mathrm{n}}\right.$ and $\mathrm{R}_{2-\mathrm{n}} \mathrm{xB}_{2-1}$ ) following the procedure described above. Clamp connections presence on three equidistant points of the colony periphery indicated that the pair was compatible, thus yielding a hybrid strain (Valencia del Toro 2002). Each new hybrid was inoculated individually on Petri dishes using $20 \mathrm{~mL}$ of MEA medium.

\section{Mycelia morphology}

The main characteristics of mycelia morphology as texture (cottony or floccose), density (high, regular or low), color (off-white, white or pale pink) and growth (scarce, regular or abundant) were identified by visual observation after the complete colonization of the Petri dishes using 20 $\mathrm{mL}$ of the MEA medium (Sobal et al., 2007).

\section{Growth monitoring of native, neohaplonts and hybrids mycelium of Pleurotus spp.}

Mycelium fragments $(0.8 \mathrm{~cm}$ diameter $)$ of the strains under study were transferred to Petri dishes using $20 \mathrm{~mL}$ of MEA and incubated in the darkness at $28^{\circ} \mathrm{C}$. Fungal growth was determined by daily measuring the diameter of the colony with a vernier until the Petri dish was completely covered. Seven replicates were measured per each strain.

\section{Area and mycelial growth rate determination}

The mycelial growth area was calculated considering that the colonies grew in a circular regular manner. The mycelial growth area was plotted as a function of time and the curve was fitted with a linear model. The mycelial growth rate $\left(\mathrm{mm}^{2} /\right.$ day) was obtained from the slope of the linear function considering the time interval from 4 to 8 days. The average growth rate values of seven replicates were reported for each sample.

\section{Statistical methods}

The statistics analyses were conducted using the IBM SPSS Statistics software v. 18. A chi-square test $\left(\chi^{2}\right.$, $\mathrm{p}<0.01)$ was used to evaluate the symmetric recovery of neohaplonts. A one-way ANOVA test and Duncan post hoc analysis $(p<0.01)$ were used to determine the effects of the different treatments on the mycelia growth rate.

\section{Results and Discussion}

\section{Pleurotus spp. native germplasm recovery}

LB-051 and LB-050 strains have no stipe and their carpophores have the appearance of a flower petal, with a smooth pileus and a firm leathery consistency. The pileus size varied from 3 to $6 \mathrm{~cm}$ of diameter. Both strains presented a mycelial morphology of cottony texture with differences in density, growth and pigmentation when growing in MEA. The LB-050 strain was characterized by an abundant growth of high density and white color, whereas the LB-051 showed regular growth and density and a pale pink color.

Pleurotus djamor studies have shown that this inter-sterile group, that is commonly found in Mexico (Valencia del Toro 2002), is formed by three different phenotypic carpophores varieties: white, grey or pink; denominated as djamor, opuntiae and salmoneostramineus, respectively (Petersen 1995a, Petersen and Hughes1999, Petersen and Ridley 1996). A taxonomic determination of 
the species was made in the Herbarium of the Faculty of Sciences - Universidad Nacional Autónoma de México (UNAM). The taxonomic study resulted in the following classification: LB-050 belongs to the Pleurotus djamor var. djamor (Rumph. Ex. Fr.) Boedijn. egistration number: 26234. On the other hand, LB-051 belongs to the Pleurotus djamor var. roseus Corner. Registration number: 26233.

\section{Mycelial recovery and characterization of neohaplonts through chemical dedikaryotization}

\section{Chemical dedikaryotization}

The two Pleurotus spp. strains showed different mechanical resistance to the chemical homogenization treatment. The LB-050 strain resisted homogenization times of up to $65 \mathrm{~s}$, whereas LB-051 strains only resisted times up to $60 \mathrm{~s}$. Table 1 lists the conditions required to obtain the monokaryotic components of the strains as well as the total neohaplonts obtained from each type (nh1 and $\mathrm{nh} 2)$. In agreement with other authors (Guerrero et al., 2007, Maldonado 2007, Morales 2009, Valencia del Toro 2002), the use of peptone-glucose solution (PGS) as a dedikaryotizing medium reduced the incubation time to $72 \mathrm{~h}$, compared to the traditional method that requires more than $120 \mathrm{~h}$ (LealLara 1980). In addition, with this method it was possible to attain symmetrical recovery of both neohaplonts for each strain. Arias-García (1998) and Arteaga-Santillas et al.
(1996) observed that the results of the chemical homogenization treatment depend on the susceptibility of the strain against the toxicity of the chemicals used and on the extent of the modification of the cell wall. Thus, the monokaryotization conditions such as homogenization time, inoculum volume and incubation time must be individually adjusted for each strain, in order to establish the optimum treatment for the symmetric recovery of neohaplonts.

\section{Mycelial morphology, color and growth rate}

Tables 2 and 3 show the main mycelial morphologic characteristics and the growth rates for the neohaplonts obtained from both strains LB-050 ( $\mathrm{B}_{1-\mathrm{n}}$ and $\left.\mathrm{B}_{2-\mathrm{n}}\right)$ and LB-051 $\left(R_{1-n}\right.$ and $\left.R_{2-n}\right)$. Neohaplonts showed two types of mycelium texture: cottony and floccose. The floccose mycelium developed a low density and scarce growth. The cottony mycelium resulted in two different types of growth: cottony with high density and abundant growth, and cottony with regular density and regular growth. Thus, the mycelial morphology of the monokaryotic components can be classified as follows: cottony with high density and abundant growth (C-high); cottony with regular density and regular growth (C-reg) and floccose with low density and scarce growth (F-low) (Figure 1). Neohaplonts presented predominantly a C-reg mycelial morphology, which accounted for $50 \%$ and $43 \%$ of the LB- 051 and LB-050 strains, respectively.

Table 1 - Conditions used for the recovery of neohaplonts of LB-050 and LB-051 strains by chemical dedikaryotized process.

\begin{tabular}{|c|c|c|c|c|c|c|c|}
\hline \multirow[t]{2}{*}{ Dikaryotic strain } & \multirow[t]{2}{*}{$\mathrm{Ht}^{*}(\mathrm{~s})$} & \multirow[t]{2}{*}{$\mathrm{Vi}^{*}(\mu \mathrm{L})$} & \multirow[t]{2}{*}{ It* (days) } & \multicolumn{3}{|c|}{ Recovered neohaplonts } & \multirow{2}{*}{$\begin{array}{l}\chi^{2} \text { test for symmetric re- } \\
\text { covery }(\text { nh1:nh } 2=1: 1)^{*}\end{array}$} \\
\hline & & & & Total & Type nh1 & Type nh2 & \\
\hline LB-050 & 60 & 100 & 3 & 7 & 6 & 1 & 3.57 \\
\hline LB-051 & 65 & 100 & 3 & 8 & 5 & 3 & 0.5 \\
\hline
\end{tabular}

* $\mathrm{Ht}$ is the time of blending; Vi is the volume of inoculum; It is the time of incubation in PGS. ** Test reference value $\chi^{2}=6.635(\mathrm{p}<0.01)$. Smaller $\chi^{2}$ values indicate no significant differences.

Table 2 - Colony morphology and growth rate of LB-050 neohaplonts grown on MEA at $28^{\circ} \mathrm{C}$.

\begin{tabular}{|c|c|c|c|c|c|c|}
\hline \multirow[t]{2}{*}{ Neohaplont (Code) } & \multirow[t]{2}{*}{ Type of neohaplont } & \multicolumn{5}{|c|}{ Mycelial characteristics } \\
\hline & & Texture & Density & Growth & Color & $\begin{array}{l}\text { Growth Rate } \\
\left(\mathrm{mm}^{2} / \text { day }\right)^{*}\end{array}$ \\
\hline $\mathrm{B}_{1-1}$ & nh1 & Cottony & High & Abundant & White & $245.160 \pm 9.168^{\mathrm{e}}$ \\
\hline $\mathrm{B}_{1-2}$ & nh1 & Cottony & Regular & Regular & White & $154.207 \pm 3.601^{\mathrm{c}}$ \\
\hline$B_{1-3}$ & nh1 & Floccose & Low & Scarce & Off-white & $18.046 \pm 1.975^{\mathrm{a}}$ \\
\hline$B_{1-4}$ & nh1 & Cottony & High & Abundant & White & $189.510 \pm 16.763^{\mathrm{d}}$ \\
\hline $\mathrm{B}_{1-5}$ & nh1 & Cottony & Regular & Regular & White & $55.281 \pm 0.611^{\mathrm{b}}$ \\
\hline$B_{1-6}$ & nh1 & Floccose & Low & Scarce & Off-white & $11.725 \pm 0.858^{\mathrm{a}}$ \\
\hline$B_{2-1}$ & $\mathrm{nh} 2$ & Cottony & Regular & Regular & White & $44.361 \pm 3.748^{\mathrm{b}}$ \\
\hline
\end{tabular}


Table 3 - Colony morphology and growth rate of LB-051 neohaplonts grown on MEA at $28^{\circ} \mathrm{C}$.

\begin{tabular}{|c|c|c|c|c|c|c|}
\hline \multirow[t]{2}{*}{ Neohaplont (Code) } & \multirow[t]{2}{*}{ Type of neohaplont } & \multicolumn{5}{|c|}{ Mycelial characteristics } \\
\hline & & Texture & Density & Growth & Color & $\begin{array}{l}\text { Growth Rate } \\
\left(\mathrm{mm}^{2} / \text { day }\right)^{*}\end{array}$ \\
\hline $\mathrm{R}_{1-1}$ & nh1 & Cottony & High & Abundant & White & $117.996 \pm 3.293^{\mathrm{d}}$ \\
\hline $\mathrm{R}_{1-2}$ & nh1 & Cottony & Regular & Regular & White & $81.243 \pm 3.211^{\mathrm{c}}$ \\
\hline $\mathrm{R}_{1-3}$ & nh1 & Cottony & High & Abundant & White & $136.928 \pm 5.822^{\mathrm{e}}$ \\
\hline $\mathrm{R}_{1-4}$ & nh1 & Floccose & Low & Scarce & Off-white & $55.692 \pm 5.906^{\mathrm{b}}$ \\
\hline $\mathrm{R}_{1-5}$ & nh1 & Floccose & Low & Scarce & Off-white & $42.516 \pm 2.546^{\mathrm{a}}$ \\
\hline $\mathrm{R}_{2-1}$ & nh2 & Cottony & Regular & Regular & Pale pink & $86.517 \pm 0.914^{\mathrm{c}}$ \\
\hline $\mathrm{R}_{2-2}$ & nh2 & Cottony & Regular & Regular & Pale pink & $84.748 \pm 2.017^{\mathrm{c}}$ \\
\hline $\mathrm{R}_{2-3}$ & nh2 & Cottony & Regular & Regular & Pale pink & $63.435 \pm 5.271^{\mathrm{b}}$ \\
\hline
\end{tabular}

* Growth rate (Value $\pm \mathrm{SD}$ ). Different letters indicated significant difference among growth rate values of neohaplonts at level $\mathrm{p}<0.01$, according to Duncan test.

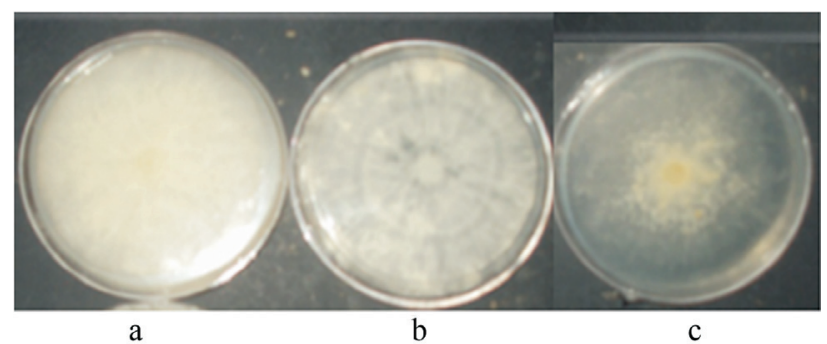

Figure 1 - Mycelium morphology type for Pleurotus spp. strains: (a) cottony texture- high density-abundant growth (C-high); (b) cottony texture-regular density-regular growth (C-reg) and (c) floccose texture-low density-scarce growth (F-low).

The color of the LB-050 cottony mycelium was white, while the LB-051 cottony mycelium presented two different colors: white and pale pink for the nh1 and nh2 neohaplonts, respectively. The floccose mycelium was off-white regardless of its parental strain. These results are consistent to those reported elsewhere (Eichlerová and Homolka 1999, Maldonado 2007), in which the morphology of monokaryotic colonies of Pleurotus spp. strains (neohaplonts and monosporic) presented differences with respect to their parental dikaryotic strains.

The mycelial growth in solid medium has been measured in different basidiomycetes such as Schizophyllum commune (Clark and Anderson 2004), Coprinus cinereus and Pleurotus ssp. (Larraya et al., 2001). Although there is not a unified criterion to report it (Baumer et al., 2008, Castro et al., 2006, Larraya et al., 2001, Larraya et al., 2002), mycelial growth is a characteristic property of each strain. In addition, this parameter can be used as a selection criterion for the edible-fungi cultivation programs considering that fast growing strains have the potential to achieve high production yields because they colonize the substrate much faster and develop better fruiting characteristics compared to the slower strains (Clark and Anderson 2004). Tables 2 and 3, present the mycelial growth rates of the 15 recovered neohaplonts. Neohaplont $\mathrm{B}_{1-1}$ resulted in the fastest growth rate at $245.160 \pm 9.168 \mathrm{~mm}^{2} /$ day; whereas neohaplont $\mathrm{B}_{1-6}$ had the slowest growth rate $\left(11.725 \pm 0.985 \mathrm{~mm}^{2} /\right.$ day $)$.

A study of the relationship between the mycelium morphology of the neohaplonts (C-high, C-reg and F-low) and their growth rate was performed. In Figure 2, it can be observed that the C-high mycelia were significantly faster than the C-reg and F-low mycelia for both LB-050 and LB-051 strains $[F(5,27)=308.968 ; \mathrm{p}<0.01]$. Eichlerová and Homolka (1999) reported that monosporic mycelia morphology was neither correlated with the growth rate, nor with the enzymatic activity. Nevertheless, Simchen (1996) and Clark and Anderson (2004) observed a correlation between morphology and growth rate for the monosporic components of the Schizophyllum commune fungi.

\section{Production and characterization of mycelial hybrid strains}

\section{Mycelial morphology}

Pairing of the 15 recovered neohaplonts yielded 56 hybrid strains that were classified into the following four groups: $\mathrm{R}_{1-\mathrm{n}} \mathrm{xB}_{1-\mathrm{n}}$ (30 hybrids), $\mathrm{R}_{1-\mathrm{n}} \mathrm{xB}_{2-1}$ (5 hybrids), $\mathrm{R}_{2-\mathrm{n}} \mathrm{XB}_{1-\mathrm{n}}\left(18\right.$ hybrids) and $\mathrm{R}_{2-\mathrm{n}} \mathrm{xB}_{2-1}$ ( 3 hybrids). The mycelial morphologies of these strains corresponded to the three types of mycelial morphology previously established for the monokaryotic components. The C-high mycelial morphology was predominant $(57.10 \%)$, followed by the F-low morphology (28.57\%), whereas the C-reg was the less frequent morphology (14.29\%) (Table 4). Hybrid strains with $\mathrm{C}$-high morphology resulted from pairing the LB-051 neohaplonts with the LB-050 neohaplonts of mycelial morphologies C-high ( $\mathrm{B}_{1-1}$ and $\left.\mathrm{B}_{1-4}\right)$ and $\mathrm{C}$-reg $\left(\mathrm{B}_{1-5}\right.$ 


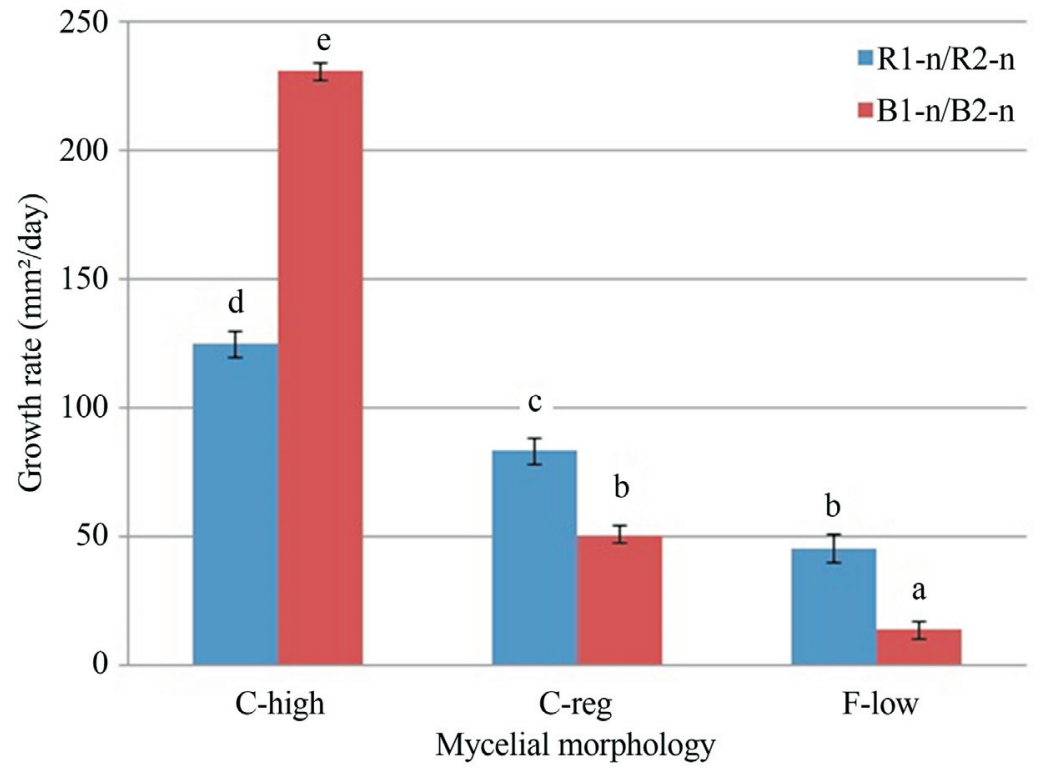

Figure 2 - Comparison of mycelium growth rate based on the morphology type for LB-050 ( $\left.\mathrm{B}_{1-\mathrm{n}} / \mathrm{B}_{2-\mathrm{n}}\right)$ and LB-051 (R $\left.\mathrm{R}_{1-\mathrm{n}} / \mathrm{R}_{2-\mathrm{n}}\right)$ neohaplonts. Cottony texture- high density-abundant growth (C-high); cottony texture-regular density-regular growth (C-reg) and floccose texture-low density-scarce growth (F-low). Different letters indicated significant difference among growth rate values of the neohaplont's morphology at level $\mathrm{p}<0.01$, according to Duncan test.

Table 4 - Compatibility of the neohaplont strains LB-050 ( $\mathrm{B}_{1-\mathrm{n}}$ and $\left.\mathrm{B}_{2-\mathrm{n}}\right)$ and LB-051 ( $\mathrm{R}_{1-\mathrm{n}}$ and $\left.\mathrm{R}_{2-\mathrm{n}}\right)$ neohaplonts and mycelium morphology of hybrid strains.

\begin{tabular}{|c|c|c|c|c|c|c|c|c|}
\hline & & \multicolumn{7}{|c|}{ LB-050 neohaplonts } \\
\hline & & $\mathrm{B}_{1-1}$ & $\mathrm{~B}_{1-2}$ & $\mathrm{~B}_{1-3}$ & $\mathrm{~B}_{1-4}$ & $\mathrm{~B}_{1-5}$ & $\mathrm{~B}_{1-6}$ & $\mathrm{~B}_{2-1}$ \\
\hline \multirow{8}{*}{$\begin{array}{l}\text { LB-051 } \\
\text { neohaplonts }\end{array}$} & $\mathrm{R}_{1-1}$ & $++^{1,1}$ & $t^{2,1}$ & $t^{3,1}$ & $+^{1,1}$ & $++^{1,1}$ & $+^{3,1}$ & $+^{1,1}$ \\
\hline & $\mathrm{R}_{1-2}$ & $+^{1,1}$ & $t^{2,1}$ & $t^{3,1}$ & $+^{1,1}$ & $+^{1,1}$ & $t^{3,1}$ & $+^{1,1}$ \\
\hline & $\mathrm{R}_{1-3}$ & $+^{1,1}$ & $+^{2,1}$ & $t^{3,1}$ & $+^{1,1}$ & $+^{1,1}$ & $+^{3,1}$ & $+^{1,1}$ \\
\hline & $\mathrm{R}_{1-4}$ & $++^{1,1}$ & $+^{2,1}$ & $t^{3,1}$ & $++^{1,1}$ & $++^{1,1}$ & $t^{3,1}$ & $++^{1,1}$ \\
\hline & $\mathrm{R}_{1-5}$ & $+^{1,1}$ & $t^{2,1}$ & $t^{3,1}$ & $+^{1,1}$ & $+^{1,1}$ & $+^{3,1}$ & $+^{1,1}$ \\
\hline & $\mathrm{R}_{2-1}$ & $++^{1,2}$ & $t^{2,2}$ & $t^{3,1}$ & $++^{1,2}$ & $+^{1,2}$ & $t^{3,1}$ & $+^{1,2}$ \\
\hline & $\mathrm{R}_{2-2}$ & $++^{1,2}$ & $t^{2,2}$ & $t^{3,1}$ & $++^{1,2}$ & $++^{1,2}$ & $t^{3,1}$ & $+^{1,2}$ \\
\hline & $\mathrm{R}_{2-3}$ & $+^{1,2}$ & $t^{2,2}$ & $t^{3,1}$ & $++^{1,2}$ & $+^{1,2}$ & $+^{3,1}$ & $+^{1,2}$ \\
\hline
\end{tabular}

$(+)$ indicates clamp formation (i.e. compatible pairing = hybrid strain). ${ }^{1,1}$ indicates cottony texture with high density, abundant growth and white mycelium; ${ }^{2,1}$ indicates cottony texture, regular density, regular growth and white mycelium; ${ }^{3,1}$ indicates floccose texture with low density, scarce growth and off-white mycelium; ${ }^{1,2}$ indicates cottony texture with high density, abundant growth and pale pink mycelium and ${ }^{2,2}$ indicates cottony texture, regular density, regular growth and pale pink mycelium.

and $\mathrm{B}_{2-1}$ ). The hybrids obtained from the neohaplont $\mathrm{B}_{1-2}$ maintained a C-reg morphology, whereas those obtained from neohaplonts $\mathrm{B}_{1-3}$ and $\mathrm{B}_{1-6}$ kept the F-low mycelial morphology independently of the LB-051 neohaplont used for pairing. Therefore, the mycelial morphology of the hybrid strains primarily depended on the dominant genetic characteristics inherited from the LB-050 neohaplonts. Hybrid strains with $\mathrm{C}$-high mycelial characteristics could not be obtained from F-low neohaplonts pairs, since these can only inherit F-low or C-reg morphology types.

\section{Mycelial color}

Resulting from the hybridization, $44.6 \%$ of the hybrid strains were white as the LB-050 strain and $26.80 \%$ of the hybrid strains inherited the pink pale color of the LB-051 strain (resulted from pairing the neohaplonts $\mathrm{R}_{2-1}, \mathrm{R}_{2-2}$ and $\mathrm{R}_{2-3}$ with the neohaplonts $\mathrm{B}_{1-1}, \mathrm{~B}_{1-2}, \mathrm{~B}_{1-4}, \mathrm{~B}_{1-5}$ and $\left.\mathrm{B}_{2-1}\right)$. The remaining $28.60 \%$ of hybrids presented an off-white color resulting from pairing any LB-051 neohaplont with neohaplonts of F-low mycelium $\left(\mathrm{B}_{1-3}\right.$ and $\left.\mathrm{B}_{1-6}\right)$. It was observed that pairing between white neohaplonts always 
produced white mycelia; whereas pink pale neohaplonts paired with white ones produced pale pink mycelia. Finally, pairing of off-white neohaplonts always resulted in off-white mycelia regardless of the other neohaplont color. These results agree with Mendel's Laws, in which the pink pale neohaplonts are probably the dominant alleles and the white and off-white neohaplonts the recessive ones.

\section{Morphology and growth rate.}

In order to study the relationship between the neohaplonts mycelial morphology and the growth rate of the resulting hybrid, the four hybrid types were subdivided into 16 subgroups, and these were regrouped depending on the native neohaplont morphology type (Table 5).
In general, the hybrids obtained from F-low neohaplonts, such as $\mathrm{R}_{1-5} \mathrm{xB}_{1-6}$, had lower growth rates (19.011 $\pm 0.902 \mathrm{~mm}^{2} /$ day) than those obtained from cottony neohaplonts, such as $\mathrm{R}_{1-3} \mathrm{xB}_{1-4}\left(937.453 \pm 24.043 \mathrm{~mm}^{2} /\right.$ day $)$ $[F(15,39)=630.381 ; \mathrm{p}<0.01]$ (Table 6). These results demonstrate that the mycelial growth rate of the hybrid strains is directly dependent on the mycelial morphology of the neohaplont. Clark and Anderson (2004) postulated that fast growing monosporic strains, have better colonization capability, fruiting and spore production, as compared to the slower strains. Considering this, the morphology of the neohaplonts can be used as a selection parameter to define the neohaplont pairs for obtaining the most productive dicaryotic strains.

Table 5 - Classification of the hybrid strains based on the neohaplonts mycelium morphology used for pairing.

\begin{tabular}{|c|c|c|c|c|}
\hline \multirow[t]{2}{*}{ Hybrid type } & \multicolumn{2}{|c|}{ Pairing of: } & \multirow[t]{2}{*}{ Subgroup* $R_{x-y x} B_{x^{\prime}-y^{\prime}}$} & \multirow[t]{2}{*}{ Hybrids } \\
\hline & $\mathrm{R}_{\mathrm{x}-\mathrm{y}}$ & $B_{x^{\prime}-y^{\prime}}$ & & \\
\hline \multirow[t]{30}{*}{$\mathrm{R}_{1-\mathrm{n}} \times \mathrm{B}_{1-\mathrm{n}}$} & nh1 & $\mathrm{nh} 1$ & C-high ${ }_{x}$ C-high & $\mathrm{R}_{1-1} \times \mathrm{B}_{1-1}$ \\
\hline & & & & $\mathrm{R}_{1-1} \times \mathrm{B}_{1-4}$ \\
\hline & & & & $\mathrm{R}_{1-3} \times \mathrm{B}_{1-1}$ \\
\hline & & & & $\mathrm{R}_{1-3} \mathrm{xB}_{1-4}$ \\
\hline & nh1 & nh1 & C-reg ${ }_{x}$ C-high & $\mathrm{R}_{1-2} \times \mathrm{B}_{1-1}$ \\
\hline & & & & $\mathrm{R}_{1-2} \mathrm{xB}_{1-4}$ \\
\hline & nh1 & nh1 & F-low ${ }_{x}$ C-high & $\mathrm{R}_{1-4} \times \mathrm{B}_{1-1}$ \\
\hline & & & & $\mathrm{R}_{1-4} \times \mathrm{B}_{1-4}$ \\
\hline & & & & $\mathrm{R}_{1-5} \times \mathrm{B}_{1-1}$ \\
\hline & & & & $\mathrm{R}_{1-5} \times \mathrm{B}_{1-4}$ \\
\hline & nh1 & nh1 & C-high ${ }_{x}$ C-reg & $\mathrm{R}_{1-1} \times \mathrm{B}_{1-2}$ \\
\hline & & & & $\mathrm{R}_{1-1} \times \mathrm{B}_{1-5}$ \\
\hline & & & & $\mathrm{R}_{1-3} \times \mathrm{B}_{1-2}$ \\
\hline & & & & $\mathrm{R}_{1-3} \times \mathrm{B}_{1-5}$ \\
\hline & nh1 & nh1 & C-reg ${ }_{x}$ C-reg & $\mathrm{R}_{1-2} \times \mathrm{B}_{1-2}$ \\
\hline & & & & $\mathrm{R}_{1-2} \times \mathrm{B}_{1-5}$ \\
\hline & nh1 & nh1 & F-low ${ }_{x}$ C-reg & $\mathrm{R}_{1-4} \times \mathrm{B}_{1-2}$ \\
\hline & & & & $\mathrm{R}_{1-4} \times \mathrm{B}_{1-5}$ \\
\hline & & & & $\mathrm{R}_{1-5} \mathrm{XB}_{1-2}$ \\
\hline & & & & $\mathrm{R}_{1-5} \times \mathrm{B}_{1-5}$ \\
\hline & nh1 & nh1 & C-high ${ }_{x}$ F-low & $\mathrm{R}_{1-1} \times \mathrm{B}_{1-3}$ \\
\hline & & & & $\mathrm{R}_{1-1} \times \mathrm{B}_{1-6}$ \\
\hline & & & & $\mathrm{R}_{1-3} \times \mathrm{B}_{1-3}$ \\
\hline & & & & $\mathrm{R}_{1-3} \times \mathrm{B}_{1-6}$ \\
\hline & nh1 & nh1 & C-reg ${ }_{x}$ F-low & $\mathrm{R}_{1-2} \times \mathrm{B}_{1-3}$ \\
\hline & & & & $\mathrm{R}_{1-2} \times \mathrm{B}_{1-6}$ \\
\hline & nh1 & nh1 & F-low ${ }_{x}$ F-low & $\mathrm{R}_{1-4} \times \mathrm{B}_{1-3}$ \\
\hline & & & & $\mathrm{R}_{1-4} \times \mathrm{B}_{1-6}$ \\
\hline & & & & $\mathrm{R}_{1-5} \times \mathrm{B}_{1-3}$ \\
\hline & & & & $\mathrm{R}_{1-5} \times \mathrm{B}_{1-6}$ \\
\hline \multirow[t]{4}{*}{$\mathrm{R}_{1-\mathrm{n}} \mathrm{XB}_{2-\mathrm{n}}$} & nh1 & nh2 & C-high ${ }_{x}$ C-reg & $\mathrm{R}_{1-1} \times \mathrm{B}_{2-1}$ \\
\hline & & & & $\mathrm{R}_{1-3} \mathrm{xB}_{2-1}$ \\
\hline & nh1 & $\mathrm{nh} 2$ & C-reg ${ }_{x}$ C-reg & $\mathrm{R}_{1-2} \mathrm{xB}_{2-1}$ \\
\hline & nh1 & $\mathrm{nh} 2$ & F-low ${ }_{x}$ C-reg & $\mathrm{R}_{1-4} \times \mathrm{B}_{2-1}$ \\
\hline
\end{tabular}




\begin{tabular}{|c|c|c|c|c|}
\hline \multirow[t]{2}{*}{ Hybrid type } & \multicolumn{2}{|c|}{ Pairing of: } & \multirow[t]{2}{*}{ Subgroup* $R_{x-y x} B_{x^{\prime}-y^{\prime}}$} & \multirow[t]{2}{*}{ Hybrids } \\
\hline & $R_{x-y}$ & $B_{x^{\prime}-y^{\prime}}$ & & \\
\hline & & & & $\mathrm{R}_{1-5} \mathrm{xB}_{2-1}$ \\
\hline \multirow[t]{18}{*}{$\mathrm{R}_{2-\mathrm{n}} \mathrm{xB}_{1-\mathrm{n}}$} & nh2 & nh1 & C-reg ${ }_{x}$ C-high & $\mathrm{R}_{2-1} \times \mathrm{B}_{1-1}$ \\
\hline & & & & $\mathrm{R}_{2-1} \times \mathrm{B}_{1-4}$ \\
\hline & & & & $\mathrm{R}_{2-2} \mathrm{XB}_{1-1}$ \\
\hline & & & & $\mathrm{R}_{2-2} \mathrm{XB}_{1-4}$ \\
\hline & & & & $\mathrm{R}_{2-3} \times \mathrm{B}_{1-1}$ \\
\hline & & & & $\mathrm{R}_{2-3} \times \mathrm{B}_{1-4}$ \\
\hline & nh2 & nh1 & C-reg ${ }_{x}$ C-reg & $\mathrm{R}_{2-1} \times \mathrm{B}_{1-2}$ \\
\hline & & & & $\mathrm{R}_{2-1} \mathrm{xB}_{1-5}$ \\
\hline & & & & $\mathrm{R}_{2-2} \mathrm{XB}_{1-2}$ \\
\hline & & & & $\mathrm{R}_{2-2} \times \mathrm{B}_{1-5}$ \\
\hline & & & & $\mathrm{R}_{2-3} \times \mathrm{B}_{1-2}$ \\
\hline & & & & $\mathrm{R}_{2-3} \times \mathrm{B}_{1-5}$ \\
\hline & nh2 & nh1 & C-reg ${ }_{x}$ F-low & $\mathrm{R}_{2-1} \times \mathrm{B}_{1-3}$ \\
\hline & & & & $\mathrm{R}_{2-1} \times \mathrm{B}_{1-6}$ \\
\hline & & & & $\mathrm{R}_{2-2} \mathrm{XB}_{1-3}$ \\
\hline & & & & $\mathrm{R}_{2-2} \mathrm{XB}_{1-6}$ \\
\hline & & & & $\mathrm{R}_{2-3} \mathrm{XB}_{1-3}$ \\
\hline & & & & $\mathrm{R}_{2-3} \times \mathrm{B}_{1-6}$ \\
\hline \multirow[t]{3}{*}{$\mathrm{R}_{2-\mathrm{n}} \mathrm{XB}_{2-\mathrm{n}}$} & nh2 & nh2 & C-reg ${ }_{x}$ C-reg & $\mathrm{R}_{2-1} \times \mathrm{B}_{2-1}$ \\
\hline & & & & $\mathrm{R}_{2-2} \mathrm{XB}_{2-1}$ \\
\hline & ${ }_{2-3} \mathrm{XB}_{2}$ & & & \\
\hline
\end{tabular}

* C-high means cottony texture- high density-abundant growth; C-reg means cottony texture-regular density-regular growth and F-low means floccose texture-low density-scarce growth.

Table 6 - Mycelium growth rate of hybrid strains selected according to the neohaplonts mycelia morphology.

\begin{tabular}{|c|c|c|c|c|}
\hline Type of hybrid & Subgroup* $R_{x-y x} B_{x^{\prime}-y^{\prime}}$ & Hybrid selected & Growth rate $\left(\mathrm{mm}^{2} / \text { day }\right)^{* *}$ & $\mathrm{R}^{* * *}$ \\
\hline \multirow[t]{9}{*}{$\mathrm{R}_{1-\mathrm{n}} \mathrm{XB}_{1-\mathrm{n}}$} & C-high ${ }_{x}$ C-high & $\mathrm{R}_{1-3} \mathrm{xB}_{1-4}$ & $937.453 \pm 24.043^{\mathrm{g}}$ & 0.9924 \\
\hline & C-reg $x$ C-high & $\mathrm{R}_{1-2} \mathrm{XB}_{1-4}$ & $1059.170 \pm 17.815^{\mathrm{h}}$ & 0.9977 \\
\hline & F-low ${ }_{x}$ C-high & $\mathrm{R}_{1-5} \mathrm{xB}_{1-4}$ & $945.270 \pm 17.401^{\mathrm{g}}$ & 0.9940 \\
\hline & C-high ${ }_{x}$ C-reg & $\mathrm{R}_{1-3} \times \mathrm{B}_{1-5}$ & $488.060 \pm 51.127^{\mathrm{d}}$ & 0.9912 \\
\hline & C-reg ${ }_{x}$ C-reg & $\mathrm{R}_{1-2} \mathrm{XB}_{1-2}$ & $204.390 \pm 3.658^{\mathrm{c}}$ & 0.9922 \\
\hline & F-low $x$ C-reg & $\mathrm{R}_{1-4} \times \mathrm{B}_{1-2}$ & $51.545 \pm 2.225^{\mathrm{a}}$ & 0.9932 \\
\hline & C-high ${ }_{x}$ F-low & $\mathrm{R}_{1-1} \times \mathrm{B}_{1-6}$ & $196.360 \pm 7.695^{\mathrm{c}}$ & 0.9960 \\
\hline & C-reg ${ }_{x}$ F-low & $\mathrm{R}_{1-2} \times \mathrm{B}_{1-3}$ & $196.090 \pm 11.135^{\mathrm{c}}$ & 0.9958 \\
\hline & F-low ${ }_{x}$ F-low & $\mathrm{R}_{1-5} \times \mathrm{B}_{1-6}$ & $19.011 \pm .902^{\mathrm{a}}$ & 0.9858 \\
\hline \multirow[t]{3}{*}{$\mathrm{R}_{1-\mathrm{n}} \mathrm{xB}_{2-1}$} & C-high ${ }_{x}$ C-reg & $\mathrm{R}_{1-3} \mathrm{xB}_{2-1}$ & $682.010 \pm 13.311^{\mathrm{f}}$ & 0.9956 \\
\hline & C-reg ${ }_{x}$ C-reg & $\mathrm{R}_{1-2} \mathrm{XB}_{2-1}$ & $478.003 \pm 5.869^{\mathrm{d}}$ & 0.9902 \\
\hline & F-low ${ }_{x}$ C-reg & $\mathrm{R}_{1-5} \mathrm{xB}_{2-1}$ & $564.553 \pm 24.532^{\mathrm{e}}$ & 0.9780 \\
\hline \multirow[t]{3}{*}{$\mathrm{R}_{2-\mathrm{n}} \mathrm{xB}_{1-\mathrm{n}}$} & C-reg ${ }_{x}$ C-high & $\mathrm{R}_{2-3} \times \mathrm{B}_{1-4}$ & $518.663 \pm 30.646^{\mathrm{e}}$ & 0.9958 \\
\hline & C-reg ${ }_{x}$ C-reg & $\mathrm{R}_{2-1} \times \mathrm{B}_{1-5}$ & $557.183 \pm 18.917^{\mathrm{e}}$ & 0.9960 \\
\hline & C-reg ${ }_{x}$ F-low & $\mathrm{R}_{2-1} \mathrm{xB}_{1-6}$ & $139.906 \pm 5.602^{\mathrm{b}}$ & 0.9817 \\
\hline $\mathrm{R}_{2-\mathrm{n}} \mathrm{xB}_{2-1}$ & C-reg $x$ C-reg & $\mathrm{R}_{2-3} \times \mathrm{B}_{2-1}$ & $477.107 \pm 2.949^{\mathrm{d}}$ & 0.9964 \\
\hline
\end{tabular}

* C-high means cottony texture- high density-abundant growth; C-reg means cottony texture-regular density-regular growth and F-low means floccose texture-low density-scarce growth. ${ }^{* *}$ Growth rate (Value $\pm \mathrm{SD}$ ). Different letters indicated significant difference among growth rate values of the hybrids at level $\mathrm{p}<0.01$, according to Duncan test. ${ }^{* * *} \mathrm{R}$ is the correlation coefficient for the linear model. 


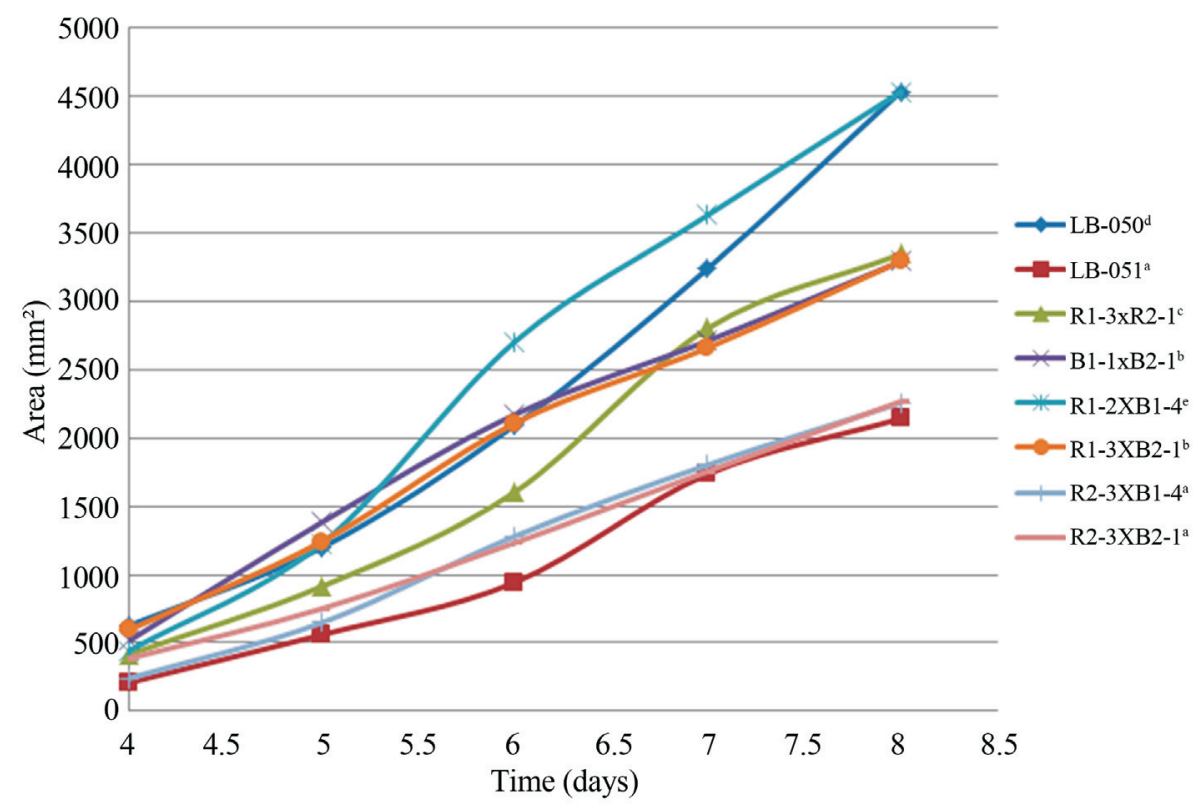

Figure 3 - Mycelium growth curves of Pleurotus spp. Strains (variance does not exceed 5\% of the means). Native strains (LB-050 and LB-051); reconstituted strains $\left(\mathrm{R}_{1-3} \times \mathrm{R}_{2-1}\right.$ and $\left.\mathrm{B}_{1-1} \mathrm{xB}_{2-1}\right)$ and hybrid strains $\left(\mathrm{R}_{1-2} \mathrm{xB}_{1-4}, \mathrm{R}_{1-3} \mathrm{xB}_{2-1}, \mathrm{R}_{2-3} \mathrm{xB}_{1-4}\right.$ and $\left.\mathrm{R}_{2-3} \mathrm{xB}_{2-1}\right)$. Different letters indicated significant difference among mycelium growth curve of the dikaryotic strains at level $\mathrm{p}<0.01$, according to Duncan test.

\section{Growth rate kinetic model}

The fastest strains were selected for plotting from each mycelium group: parental (LB-050 and LB-051), reconstituted $\left(\mathrm{R}_{1-3} \mathrm{xB}_{2-1}\right.$ and $\left.\mathrm{B}_{1-1} \mathrm{xB}_{2-1}\right)$ and hybrids $\left(\mathrm{R}_{1-2} \mathrm{xB}_{1-4}\right.$, $\mathrm{R}_{1-3} \mathrm{XB}_{2-1}, \mathrm{R}_{2-3} \mathrm{xB}_{1-4}$ and $\left.\mathrm{R}_{2-3} \mathrm{xB}_{2-1}\right)$.

In general, Pleurotus ssp. strains growth presented a short lag phase $(<3$ days $)$, while the exponential phase lasted just about 4 days. According to this, the kinetics studies were stopped before the stationary phase was reached ( 8 days). Figure 3 depicts the mycelial growth curves (colony area vs. time) of selected Pleurotus ssp. dikaryotic strains grown in MEA medium for the period of time from 4 to 8 days of incubation, which correspond to the log phase. So, the mycelial growth kinetics curves of neohaplonts and dikaryons were adjusted to the linear model : $\mathrm{Y}=\mathrm{mx}+\mathrm{b}$, where $\mathrm{Y}$ is the accumulated mycelial growth area $\left(\mathrm{mm}^{2}\right)$; $\mathrm{x}$ is the time (days), $\mathrm{m}$ is the slope that represents the growth rate $\left(\mathrm{mm}^{2} /\right.$ day $)$ and $b$ is the $y$-intercept. These results were similar to those reported by Sánchez (2001) for the Pleurotus ostreatus strains in which the growth curve was linear, too. Authors elsewhere reported that the mycelial growths of other fungi such as Lentinula edodes (Castro et al., 2006), Pycnoporus sanguineus (Baumer et al., 2008) and Monascus purpureus (Pacífico et al., 2005) were better fitted with an exponential model. The differences in the growth curve models are due to the fact that each strain has a distinctive enzymatic adaptability to the culturing solid medium. In addition, the models consider different growing time intervals and method to quantify mycelial growth such as: radio, area and rate.

\section{Growth rate assessment of selected strains}

The one-way ANOVA showed statistically significant differences in the growth rates of the Pleurotus spp. strains that were compared $[F(7,22)=442.810 ; \mathrm{p}<0.01]$. The hybrid strain $\mathrm{R}_{1-2} \mathrm{xB}_{1-4}$ from the $\mathrm{R}_{1-\mathrm{n}} \mathrm{xB}_{1-\mathrm{n}}$ type had the highest growth rate $\left(1059.170 \pm 17.815 \mathrm{~mm}^{2} /\right.$ day $)$, followed by the LB-050 parental strain $(986.388 \pm 6.017$ $\mathrm{mm}^{2}$ /day), whereas the hybrid strain $\mathrm{R}_{2-3} \mathrm{xB}_{2-1}$ from the $\mathrm{R}_{2-\mathrm{n}} \mathrm{xB}_{2-\mathrm{n}}$ type had the lowest rate $(477.107 \pm 2.949$ $\mathrm{mm}^{2}$ /day) (Table 7). Hence, pairing of compatible neohaplonts resulted in hybrid strains which can improved mycelial growth with respect to the parental strains. On the other hand, there was a reduction on the mycelial growth rate for the LB-050 reconstituted strain $(688.492 \pm 34.187$ $\mathrm{mm}^{2} /$ day) compared to the parental one $(986.388 \pm 6.017$ $\mathrm{mm}^{2} /$ day). In contrast, the mycelial growth rate of the LB-051 reconstituted strain $\left(775.322 \pm 5.554 \mathrm{~mm}^{2} /\right.$ day $)$ was higher than that of the native strain $(504.340 \pm 9.723$ $\mathrm{mm}^{2} /$ day). This might be due to the large variability of the neohaplonts nuclei which may have prompted that the phenotypical characteristics that were not present in the parental dikaryon could be expressed by the reconstituted strain.

\section{Conclusions}

The germplasm of two Pleurotus ssp. native strains from the Mexican Mixtec region was isolated, which constitutes one of the first reports of these fungi in the region. Chemical dedikaryotization using a peptone-glucose solu- 


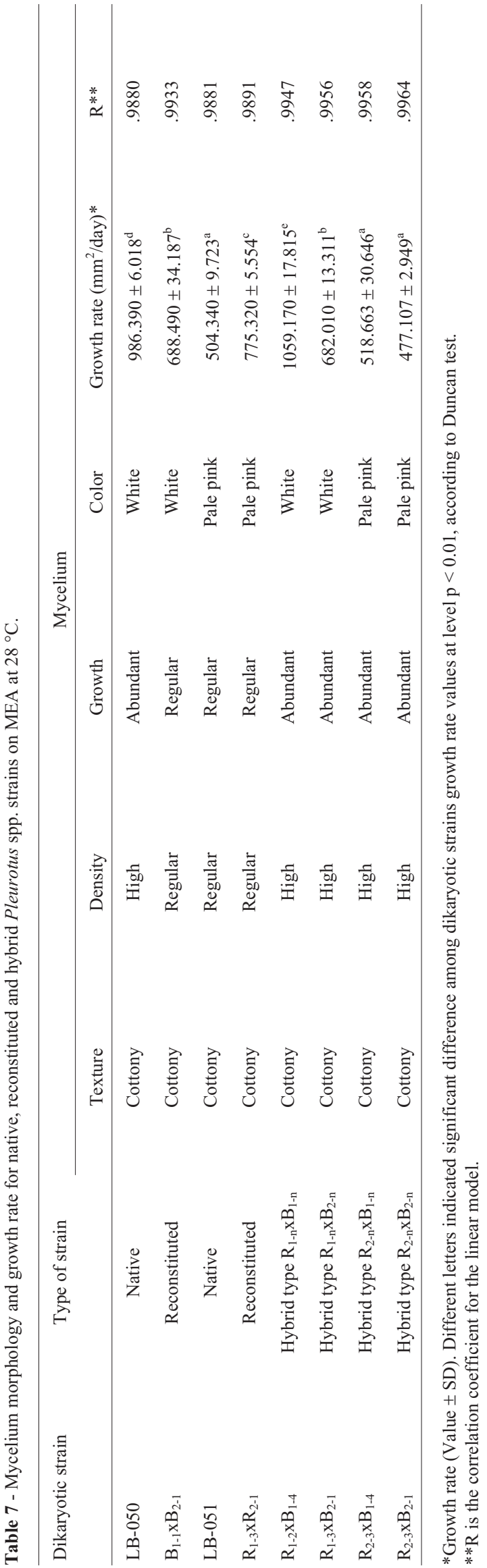

tion allowed the symmetrical recovery of both monokaryotic components (nh1:nh2) from the native strains. The mycelium morphologic characteristics and growth rates of the strains varied remarkably, in which both properties are directly related. The cottony strains with high density and exuberant growth had higher growth rates compared to those that developed a floccose texture, low density and scarce growth. The neohaplonts morphology and growth rate determined the mycelial growth characteristics of the hybrid strains; therefore, selection of the fast growing cottony neohaplonts promoted the production of fast growing hybrid strains. A linear model had a good fit to the mycelial growth kinetics of both monokaryotic and dikaryotic strains. The use of neohaplonts compatible pairing promoted the production of strains with higher mycelial growth rates in comparison with those of the native strains. This might result in the production of strains with a high production and commercial potential.

\section{Acknowledgments}

We want to thank the financial support provided by the Universidad Tecnológica de la Mixteca, the Instituto Politécnico Nacional (IPN-SIP: 20121525), Consejo Nacional de Ciencia y Tecnología (CB-2008-105683) and the Instituto de Ciencia y Tecnología del D.F. (ICYTDF-PICSO12-096). We also would like to thank Dr. Rogelio Valadez Blanco for his editorial support and Mrs. Juliana A. De los Santos Vera for the English assistance during preparation of this manuscript.

\section{References}

Aguilar A, Martínez-Carrera D; Macías A, Sánchez M, De Bauer LI, Martínez A (2002) Fundamental trends in rural mushroom cultivation in Mexico and their significance for rural development. Proceedings of the IV International Conference on Mushroom Biology and Mushroom Products, Cuernavaca, Mexico, p. 421-431.

Arias-García A (1998) Selección de cepas de Pleurotus ostreatus para el cultivo comercial por apareamiento entre neohaplontes. M.Sc. Thesis, Universidad Nacional Autónoma de México, México, D.F, 165 p.

Arteaga-Santillas SE, Ramírez-Carrillo R, Leal-Lara H (1996) Desdicariotización excéntrica de Lentinus spp. Rev Mex Micol 12:15-21.

Baumer JD, Mas Diego JM, Pacheco SMV, Morgado AFM, Furigo AF (2008) Comparative study of mycelial growth and production of cinnabarin by different strains of Pycnoporus sanguineus. BIOFAR 2:1-5.

Castro MR, Souza PJ, Eira AF (2006) Digital monitoring of mycelium growth kinetics and vigor of Shiitake (Lentinula edodes Berk. Pegler) on agar medium. Braz J Microbiol 37:90-95.

Chang ST, Miles PG (2004) Mushrooms: Cultivation, nutritional value, medicinal effect and environmental impact. CRS Press, Boca Raton. 
Clark TA, Anderson JB (2004) Dikaryons of the basidiomycete fungus Schizophyllum commune: Evolution in long term culture. Gen 167:1663-1675.

De León-Monzón JH, Sánchez JE, Nahed-Toral J (2004) El cultivo de Pleurotus ostreatus en los altos de Chiapas. Rev Mex Micol 18:31-38.

Eichlerová I, Homolka L (1999) Preparation and crossing of basidiospore-derived monokaryons-a useful tool for obtaining laccase and other ligninolytic enzyme higher-producing dikaryotic strains of Pleurotus ostreatus. Antonie Leeuwenhoek 75:321-327.

Gregori A, Svagelj M, Pohleven J (2007) Cultivation techniques and medicinal properties of Pleurotus spp. Food Technol Biotechnol 45:238-249.

Guerrero TJV, Juárez MAB, Tapia SA (2007) Obtención de componentes monocarióticos de hongos comestibles del género Pleurotus. Thesis, Unidad Profesional Interdisciplinaria de Biotecnología. México, D.F., 60 p.

Jose N, Ajith TA, Jananrdhanan KK (2002) Antioxidant, antiinflammatory, and antitumor activities of culinarymedicinal mushroom Pleurotus pulmonarius (Fr.) Quel. (Agaricomycetidae). Int J Med Mush 4:329-335.

Kashangura C, Hallsworth JE, Mswaka AY (2006) Phenotypic diversity amongst strains of Pleurotus sajor-caju: Implications for cultivation in arid environments. Mycol Res 10:312-317.

Larraya L, Pérez G, Iribarren I, Blanco JA, Alfonso M, Pisabarro AG, Ramírez L (2001) Relationship between monokaryotic growth rate and mating type in the edible basidiomycete Pleurotus ostreatus. Appl Environ Microbiol 67:3385-3390.

Larraya L, Idareta E, Arana D, Ritter E, Pisabarro AG, Ramírez L (2002) Quantitative trait loci controlling vegetative growth rate in the edible basidiomycete Pleurotus ostreatus. Appl Environ Microbiol 68:1109-1114.

Leal-Lara H (1980) Sporelessness in basidiomycete Pleurotus ostreatus (Jacq Ex Fr.) Kummer. A genetical study by means of a new dedikaryotization method. Ph.D. Thesis, Marburg University,, Marburg, 177 p.

Leal-Lara H, Eger-Hummel G (1982) A monokaryotization method its use for genetic studies in wood-rooting basidiomycetes. Theor Appl Genet 61:65-68.

Lindequist U, Timo HJ, Niedermeyer S, Wolf D (2005) The pharmacological potential of mushrooms. eCAM 2(3):285-299.

Lull C, Wichers HJ, Savelkoul HFJ (2005) Antiinflammatory and immunomodulating properties of fungal metabolites. Mediators Inflamm 2:63-80.

Maldonado AYI (2007) Obtención de cepas híbridas de Pleurotus spp. por apareamiento de neohaplontes compatibles. M.Sc. Thesis, Unidad Profesional Interdisciplinaria de Biotecnología, México, D.F., 125 p.

Martínez-Carrera D (2002). Current development of mushroom biotechnology in Latin America. Micol Apl Int 14:61-74.

Martínez-Carrera D, López-Martínez LA (2010) Historia del cultivo comercial de hogos en México: Éxitos y fracasos durante el periodo 1991-2009. In: Martínez-Carrera, D., Cuvertto, N., Sobal, N., Morales, P., Mora, V.M. (eds) Hacia un Desarrollo Sostenible del Sistema de Producción-Consumo de los Hongos Comestibles y Medicinales en Latinoamérica: Avances y Perspectivas en el Siglo XXI. Colegio de Posgraduados, Puebla, México, pp 513-551.
Mata G, Salmones D (2003) Edible mushroom cultivation at the Institute of Ecology in Mexico. Micol Apl Int 15:23-29.

Mayet Y, Martínez-Carrera D, Sánchez M, Macías A, Moras S, Estrada A (2004) Consumption of edible mushrooms in developing countries: The case of Mexico. Mush Sci 16:687696.

Morales BV (2009) Obtención de cepas híbridas de Pleurotus spp. a partir de cepas parentales blancas. Thesis, Unidad Profesional Interdisciplinaria de Biotecnología, México, D.F., $39 \mathrm{p}$.

Ng TB, Wang HX (2004) A novel ribonuclease from fruiting bodies of the common edible mushroom Pleurotus eryngii. Peptides 25:1365-1368.

Novotny C, Erbanova P, Sasek V, Kubatova A, Cajthaml T, Lang E, Krahl J, Zadrazil F (1999) Extracellular oxidative enzyme production and $\mathrm{PAH}$ removal in soil by exploratory mycelium of white rot fungi. Biodegradation 10:159-168.

Novotny C, Rawal B, Bhatt M, Patel M, Sasek V, Molitoris HP (2001) Capacity of Irpex lacteus and Pleurotus ostreatus for decolorization of chemically different dyes. J Biotech 89:113-122.

Nuhu A, Ki NY, Jae SL, Hae JC, Mi JS, Tae SL (2011) Dietary effect of Pleurotus eryngii on biochemical function and histology in hypercholesterolemic rats. Saudi J Biol Sci 18:403409.

Pacífico DGD, Ferreira FC, Kilikian BV (2005) Influencia da velocidade específica de crescimento de Monascus purpureus ATCCC 36928 na produção de pigmentos vermelhos. Anais do XV Simpósio Nacional de Bioprocessos, Brasil, p. 1-7.

Papaspyridi LM, Aligiannis N, Christakopoulos P, Skaltsounis L, Fokialakis N (2011) Production of bioactive metabolites with pharmaceutical and nutraceutical interest by submerged fermentation of Pleurotus ostreatus in a batch stirred tank bioreactor. Proc Food Sci 1:1746-1752.

Petersen RH (1995a) Contributions of mating studies to mushroom systematics. Can. J. Bot 73:S831-S842.

Petersen RH (1995b) There's more to a mushroom than meets the eye: Mating studies in the Agarical. Mycologia 87:1-17.

Petersen RH, Hughes K (1999) Species and speciation in mushrooms. Biosci 49:440-452.

Petersen RH, Ridley SG (1996) A newzealand Pleurotus with multiple-species sexual compatibility. Mycologia 88:198-207.

Reis FS, Barros L, Martins A, Ferreira I (2012) Chemical composition and nutritional value of the most widely appreciated cultivated mushrooms: An inter-species comparative study. Food Chem Toxicol 50:191-197.

Sánchez JE (2001) Crecimiento y fructificación. In: Sánchez, J.E., Royse, D.J. (eds) La Biología y el Cultivo de Pleurotus ostreatus. El Colegio de la Frontera Sur, México, D.F., pp 51-66.

Simchen G (1996) Monokaryotic variation and haploid selection in Schizophyllum commune. Heredity 21:241-263.

Sobal M, Martínez-Carrera D, Morales P, Roussos S (2007) Classical characterization of mushroom genetic resources from temperate and tropical regions of Mexico. Micol Apl Int 19:15-23.

Valencia del Toro G (2002) Estudios sobre la expresión del color de los esporóforos de Pleurotus spp. por apareamiento de neohaplontes compatibles y progenies monospóricas. Ph.D. 
Thesis, Universidad Nacional Autónoma de México, México, D.F., 123 p.

Vigalys R, Moncalvo JM, Liou, SR, Volovsek M (1996) Recent advances in molecular systematics of the genus Pleurotus. In: Royse, D.J. (ed) Mushroom Biology and Mushroom Products. Pennsylvania State University, Pennsylvania, pp 581-583.

Vigalys R, Smith A, Lin-Sun BL (1994) Ancient and recent patterns of geographic speciation in the oyster mushroom Pleurotus revealed by phylogenetic analysis of ribosomal DNA sequences. Evolution 91:4599-4603.

Vigalys R, Smith A, Lin-Sun BL, Miller OK (1993) Interesterility groups in the Pleurotus ostreatus complex from the conti- nental United States and adjacent Canada. Can J Bot 71:113-128.

Vyas BRM, Molitoris HP (1995) Involvement of an extracellular $\mathrm{H} 2 \mathrm{O} 2$-dependent ligninolytic activity of the white rot fungus Pleurotus ostreatus in the decolorization of remazol brillant blue R. Appl Environ Microbiol 61:3919-3927.

All the content of the journal, except where otherwise noted, is licensed under a Creative Commons License CC BY-NC. 